\title{
Multiple brain lesions in a young man with hypernatraemia
}

\author{
Ines Rego, ${ }^{1}$ Duarte Vieira, ${ }^{1}$ Filipe Correia, ${ }^{2}$ Jorge Resende Pereira ${ }^{1}$ \\ 1Department of Neuroradiology, Hospital Pedro Hispano, Porto, Portugal; \\ ${ }^{2}$ Department of Neurology, Hospital Pedro Hispano, Porto, Portugal
}

Correspondence to Dr Ines Rego, i.cabralrego@gmail.com

\section{DESCRIPTION}

A 47-year-old patient with a history of chronic alcoholism was admitted to our hospital with sudden loss of consciousness, respiratory failure and severe hypernatraemia $(173 \mathrm{mEq} / \mathrm{l})$; he had no other alterations in routine laboratory analyses. During admittance he experienced mental status fluctuations and developed a spastic tetraparesis, a bilateral Babinski sign and a bilateral facial paresis (locked in status). Brain MRI (figure 1) showed symmetric lesions in the pons and thalami with areas of restricted diffusion and no significant mass effect. The pons lesion spared the external pontine fibres and had a trident shape. Clinical history together with MR images suggested an osmotic demyelination syndrome (ODS), specifically a case of central pontine and extrapontine myelinolysis. ODS is a rare condition caused by severe electrolyte imbalance. ${ }^{1}$
It usually occurs during a rapid iatrogenic correction of hyponatraemia but has sometimes been described in a hypernatraemia context without sudden deviations of sodium concentration. ${ }^{2}$ It puts the nerve cells, particularly oligodendrocytes, at risk of cellular dehydration and demyelination. Alcohol addicts and malnourished individuals are at higher risk of developing it because they usually have a deficiency in organic osmolytes. ${ }^{3}$ In this patient's case alcoholism probably acted as a predisposing factor. ${ }^{2}{ }^{3}$ Myelinolysis predominantly affects the pons due to the intercrossing arrangement of oligodendrocytes, which limits the ability of these cells to increase their volume. ${ }^{3}$ Extrapontine myelinolysis occurs in $10 \%$ of the cases. The patient's hypernatraemia was slowly corrected but his condition has not improved; he is currently in a long-term care unit.

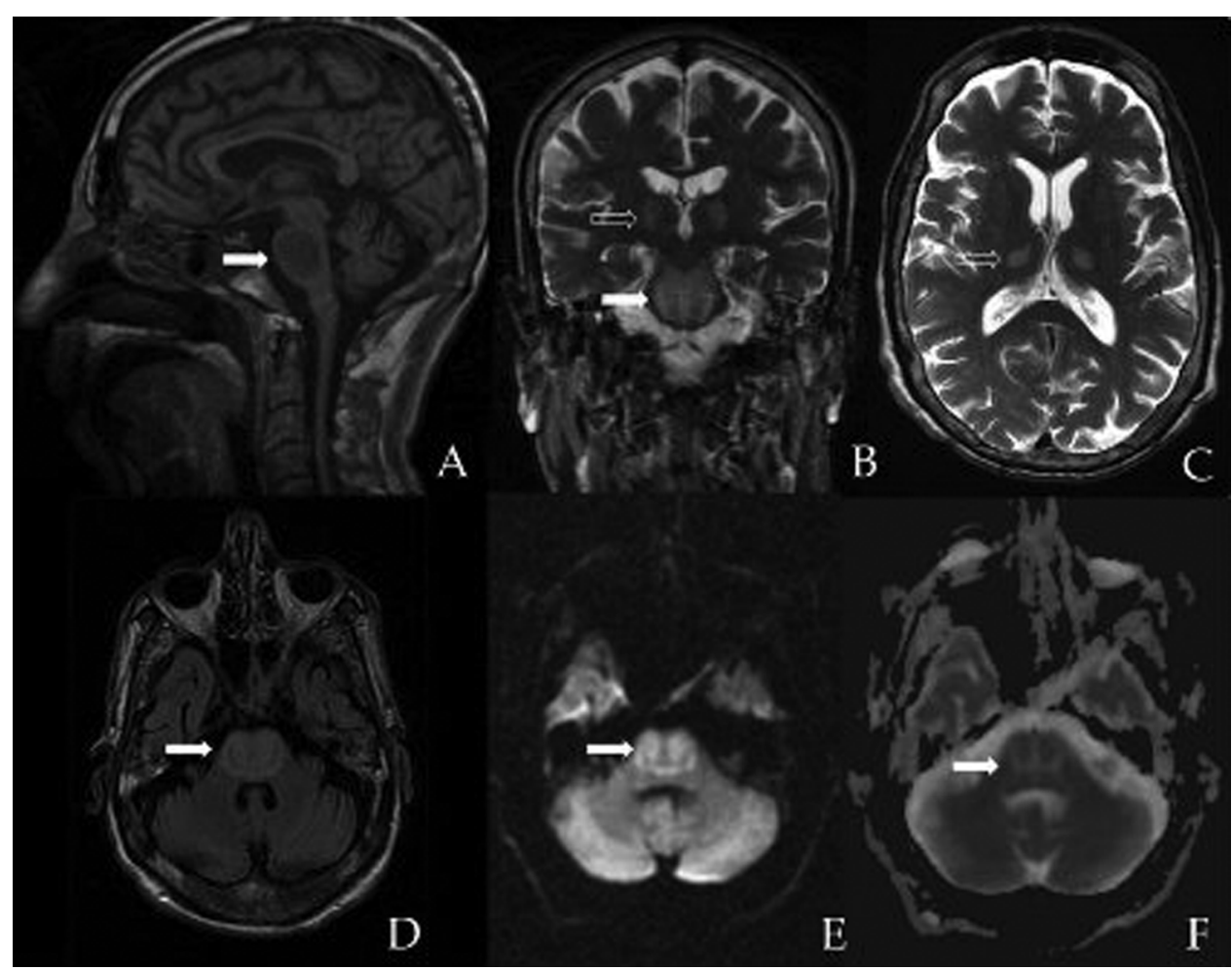

Figure 1 (A) Sagital T1FSE; (B, C) Coronal and axial T2FSE; (D) Axial FLAIR; (E, F): anisotropic diffusion study (b1000 and ADC map, respectively). The images show a symmetric central pontine lesion (arrows), sparing the peripheral fibres, with a typical trident shape and areas of restricted diffusion. Also note, in images $B$ and $C$, the symmetric thalamic lesions (open arrows). 


\section{BMJ Case Reports}

\section{Learning points}

- OSD is a rare disorder that should be suspected in cases of unexplained neurologic deficits associated with electrolyte imbalance.

- MRI is useful in the diagnosis revealing characteristic, trident shape, pontine lesions.

- Alcoholism and malnutrition are important predisposing factors.
Competing interests None.

Patient consent Obtained.

\section{REFERENCES}

1. Naik KR, Saroja A0. Seasonal postpartum hypernatremic encephalopathy with osmotic extrapontine myelinolysis and rhabdomyolysis. J Neurol Sci 2010;291:5-11.

2. An JY, Park SK, Han SR, et al. Central pontine and extrapontine myelinolysis that developed during alcohol withdrawal, without hyponatremia, in a chronic alcoholic. Intern Med 2010:49:615-8.

3. Howard SA, Barletta JA, Klufas RA, et al. Best cases from the AFIP: osmotic demyelination syndrome. Radiographics 2009;29:933-8.

This pdf has been created automatically from the final edited text and images.

Copyright 2012 BMJ Publishing Group. All rights reserved. For permission to reuse any of this content visit http://group.bmj.com/group/rights-licensing/permissions.

BMJ Case Report Fellows may re-use this article for personal use and teaching without any further permission.

Please cite this article as follows (you will need to access the article online to obtain the date of publication).

Rego I, Vieira D, Correia F, Pereira JR. Multiple brain lesions in a young man with hypernatraemia. BMJ Case Reports 2012;

10.1136/bcr.11.2011.5198, Published XXX

Become a Fellow of BMJ Case Reports today and you can:

- Submit as many cases as you like

- Enjoy fast sympathetic peer review and rapid publication of accepted articles

- Access all the published articles

Re-use any of the published material for personal use and teaching without further permission

For information on Institutional Fellowships contact consortiasales@bmjgroup.com

Visit casereports.bmj.com for more articles like this and to become a Fellow

Keep up to date with all published cases by signing up for an alert (all we need is your email address) http://casereports.bmj.com/cgi/alerts/etoc 